\title{
Demystifying the Growth Story of Indian Passenger Car Industry
}

\author{
Utpal Chattopadhyay
}

\begin{abstract}
The last decade (2002 to 2012) has been quite remarkable for the Indian passenger car industry because during this period it made steady progress in all fronts, production, domestic sales and exports. The era also saw industry's gradual ascent to global power. India now is the sixth largest producer of cars and one of the fastest growing automobile markets in the world. It is home to almost all major global automobile brands, which together contribute more than three-fourths of total production and domestic sales. The achievement of Indian industry is even more significant because it came at a time when the world automobile industry was grappling with crises. The paper identifies the major factors behind India's spectacular success. India growth story was identified to be the key. Other important factors include global shift in automobile industry, favourable policies of Indian governments and positive role of supporting industries like auto components, financial sector etc.
\end{abstract}

Index Terms-Automobile industry, global shift, india growth story, passenger car segment in India.

\section{INTRODUCTION}

Worldwide the automobile industry, including the passenger car segment, is passing through difficult times. In India also, the industry is currently facing sluggish demand, mainly caused by economic slowdown and rising fuel prices. During March 2013, car sales fell by 22.5 per cent which is the fifth consecutive decline in monthly sales in the same financial year. Overall, 2012-13 has not been a good year for the passenger car industry in India as it experienced 6.7 per cent fall in domestic sales. Almost all major car manufacturers based in India, domestic or foreign, have suffered on sales. For instance, the Indian major Tata Motors' domestic sales of passenger vehicles fell by 29.2 per cent during the year [1].

Notwithstanding its current position, the passenger car industry in India had witnessed a happy saga of non-stop growth for a long period. The last time when it experienced a contraction in sales was 2001-02, which is more than a decade ago. Post-2008 economic crisis, when most of the world economies experienced drastic falls in their car sales, the Indian market remained upbeat with positive growth in production and sales. This reflects versatility of the Indian industry which has undergone major restructuring since economic liberalization was initiated in the country in early 1990s. During the period of liberalization, many global automobile manufacturers like Ford, General Motors,

Manuscript received April 19, 2013; revised June 20, 2013.

Utpal Chattopadhyay is with the National Institute of Industrial Engineering (NITIE), Vihar Lake, Mumbai-400087, India (e-mail: utuchat@ gmail.com).
Toyota, Honda, Hyundai, Volkswagen etc. have entered into Indian market and each one of them has set up its own manufacturing facilities within India. The only foreign company that was operational prior to this was Suzuki Motor Company of Japan that entered into Indian territory in early eighties through a joint venture with a Government (of India) owned enterprise. These auto majors together are not only meeting bulk of local demand but also catering to various overseas markets from their bases in India. They are giving tough competition to indigenous car makers like Tata Motors, Mahindra \& Mahindra etc. The modern passenger car industry in India is characterized by intense competition among Indian and foreign players who are offering a large variety of products that are technologically sound, price competitive and meet various global standards on safety and environment.

But it was a long journey for the industry to reach to this stage from a humble beginning in the late forties. Even till 1980, there were only a few car manufacturers in India. The majority of market share was held by two domestic players, each one of whom was producing a limited number of models based on outdated technology acquired from their (respective) foreign partners. It was a predominantly sellers' market and the Indian consumers had very little choice before them because of limited options in the domestic market and prohibitively high cost of foreign vehicles due to excessive import duty. Indian market was protected from foreign competition and many regulatory measures prevailed in the domestic economy. This coupled with limited demand for automobiles prevented any firm to go for expansion. The scene started changing only after large scale production of affordable cars was undertaken in the country from mid-eighties. Since then the industry had made continuous progress and in that process it achieved many milestones. India is now a leading producer of automobiles and one of the fastest growing car markets in the world.

The industry had many ups and downs in its long journey. But the last decade was quite remarkable for the Indian passenger car industry because during this period it made a steady progress in all fronts. The industry's global image also improved drastically. In 2002, the government policy for the first time allowed 100 percent foreign direct investment (FDI) in automobiles through automatic route. This spurred higher growth in the sector through increased inflow of foreign investments. Besides being in a continuous growth trajectory in the face of global meltdown, Indian car industry emerged as the sixth largest producer in the world (refer Table II). Simultaneously, the indigenous car industry made speedy progress and the cheapest car of the world was born in India in the form of Tata Nano.

Though entry of foreign players into India started earlier as 
part of the global shift process, it is during this decade the foreign manufacturers gained considerable strength in the domestic market. For many foreign car makers, India now holds the key for their future global growth strategies. On the other hand, the decade also saw rising aspirations of a few local companies who are trying to make their global footprints. And all these happened at a time when the world automobile industry was under serious threat due to several crises.

The unprecedented success of Indian industry in the last decade has raised curiosity among many including the industry experts, researchers and policy makers. This paper makes an attempt to unfold this mystery. The focus of the paper is on the performance of Indian passenger vehicle industry (comprising passenger cars and utility vehicles) during the last ten years starting from 2002. It tries to offer an explanation how Indian industry could do so well in the midst of global uncertainties. Rest of the discussions in the paper is organized as follows. The next section presents a brief overview of Indian automobile industry. The third section explains various phases of the development in the industry spanning over five decades. The following section, however, focuses on the last decade, called as the decade of incessant growth. The fifth section forms the core of the discussions as it identifies the major reasons behind India's spectacular success in the last decade. Summary and conclusions are presented in the last section.

\section{INDIAN AUTOMOBILE INDUSTRY- A BRIEF OVERVIEW}

Automobile industry is often called 'the industry of industries' because of its key contribution to the industrial development of a nation. It is an industry that affects various other industries, both manufacturing and services, via forward and backward linkages. The global automobile industry is of great significance as it employs nine million people directly that accounts for five percent of world's total manufacturing employment. The industry also employs more than forty million people indirectly [2]. World automobile production is concentrated in three major regions, viz. North America, Europe and Asia. In the recent past, a lot of restructuring has happened in world automobile industry. India has emerged as a dominant player along with a few other Asian nations like China, South Korea, besides the traditional giant Japan.

India's automotive industry plays a pivotal role because of its significant contribution towards the economy, in general, and manufacturing sector, in particular. India remained an agro-based economy for long. But, of late, agriculture contributes approximately 14 percent of GDP while the share of services has increased to about 60 percent [3]. The manufacturing sector, on the other hand, has been stagnating at around 15-16 percent of GDP for quite some time. The automotive industry in India accounts for about 6 percent of national GDP and 22 percent of manufacturing GDP. It contributes more than one-fifth of total excise duty collection in the country and provides direct and indirect employment to 13.1 million people. Today, India the largest manufacturer of tractors, second largest manufacturer of two wheelers, fifth largest manufacturer of commercial vehicles and the fourth largest passenger car market in Asia [4]. India's automobile industry has experienced a stupendous growth in the past and it has huge future potential. It would not be an exaggeration to say that if India has to achieve 25\% manufacturing GDP in a decade's time, a target set by the National Manufacturing Policy 2011, its automobile industry has to contribute immensely.

Typically, the automotive industry consists of two major segments namely the automobile manufacturers, also termed as original equipment manufacturers (OEMs), and the auto components manufacturers. India enjoys competitive advantage in manufacturing of both vehicles and automotive components because of its strong engineering base and cost effective manufacturing. In the year 2010-11, the total turnover of Indian automotive industry stood at US\$ 73 billion. In the same year, the auto component industry in India had a turnover of about US\$ 40 billion with exports above US\$ 5 billion [5].

Passenger vehicles constitute more than 15 percent of all motor vehicles produced in India (2011-12). But true economic importance of the sector is much more than what gets reflected by its volume alone. India is among the top ten producers of cars in the world and home to as many as 19 manufacturers of passenger cars and multi-utility vehicles that include all major global players. The available data from the Society of Indian Automobile Manufacturers (SIAM) indicate that India has made a rapid growth in the production of all categories of vehicles including cars. Between 2006-07 and 2011-12, while production (volume) of all vehicles increased by about 13 percent, the passenger vehicle segment witnessed a growth (CARG) above 15 percent. India has also emerged as a global hub for small car manufacturing. During 2011-12, India exported 2.9 million vehicles to more than 40 countries which included 0.5 million passenger cars and 1.94 million two wheelers. The export-intensity of the industry has been increasing over time. Presently, out of every 100 passenger vehicles manufactured in India, about 16 get sold in overseas market. The progress made in the production and exports of passenger vehicles during the last five years are reported in table I.

TABLE I: TREND IN AUTOMOBILE PRODUCTION AND EXPORT IN INDIA (2007-08 TO 2011-12)

\begin{tabular}{|l|r|r|r|r|}
\hline \multirow{2}{*}{ Year } & \multicolumn{2}{|c|}{$\begin{array}{c}\text { Production } \\
\text { (In '000 number) }\end{array}$} & \multicolumn{2}{c|}{$\begin{array}{c}\text { Export } \\
\text { (In '000 number) }\end{array}$} \\
\cline { 2 - 5 } & $\begin{array}{c}\text { Passenger } \\
\text { Vehicles }\end{array}$ & $\begin{array}{c}\text { All } \\
\text { Vehicles }\end{array}$ & $\begin{array}{c}\text { Passenger } \\
\text { Vehicles }\end{array}$ & $\begin{array}{c}\text { All } \\
\text { Vehicles }\end{array}$ \\
\hline $2007-08$ & 1,778 & 10,854 & 218 & 1,238 \\
\hline $2008-09$ & 1,839 & 11,172 & 336 & 1,531 \\
\hline $2009-10$ & 2,357 & 14,057 & 446 & 1,804 \\
\hline $2010-11$ & 2,983 & 17,892 & 444 & 2,320 \\
\hline $2011-12$ & 3,124 & 20,366 & 507 & 2,910 \\
\hline
\end{tabular}

\section{THE BUILD Up OF GROWTH STORY}

The history of passenger car industry in India can be traced back to the year 1928, when General Motors (GM) set up an assembly plant at Bombay (now Mumbai). Besides cars, 
GM's Bombay plant used to assemble trucks, all from imported completely knocked down (CKD) kits from USA. Within next two to three years, Ford Motor Company also established two assembly plants in India, one in Madras (now Chennai) and another in Calcutta (now Kolkata). In the following decade (i.e. during 1940s) three new plants were established in India by the leading Indian industrial groups. The Hindustan Motors Limited (HM) came into existence in 1942 by the initiative of the Birla Group with its plant located in Uttarpara, a suburb of Calcutta. Two years later, the Walchand Group set up Premier Automobile Limited (PAL) in Bombay. In 1948, when the Standard Motor Product of India Limited (SMPI) came up in Madras, it earned the distinction of the first car manufacturing company to be established in post-independent India. However, actual manufacturing of cars within India started a little later, in early fifties. Since then and up to beginning of the last decade has been a really long period during which the industry has undergone many changes. This time period can be split into three distinct phases of development. The first phase which spreads over three decades from 1950 saw a slow but steady growth in the industry. The second (1980-1990) and the third phase (1990-2000) though had a duration of only ten years, in each period the Indian automobile industry had made rapid progress. While the second phase was more of a period of domestic consolidation, the third phase actually led to gradual integration of Indian industry into global automobile chain. Major developments affecting the industry in each of the above three phases are discussed in the following paragraphs.

\section{A. First Phase: 1950-1980}

In 1953, the Government of India permitted only those projects to operate in the country that had phased manufacturing programmes. This led to the exit of GM and Ford whose interests were confined only to assembly of cars with no serious ambition of taking up manufacturing within India. Thus, the Indian market was left open to only three manufacturers from India, viz. HM, PAL and the SMPI. HM was the first unit to manufacture passenger cars. Its product portfolio gradually included Hindustan 10, Hindustan 14, Landmaster and different models of Ambassador. The HM had initial collaboration with Nuffield of UK. The PAL, on other hand, started manufacturing of cars for Indian market with the technical collaboration of Italian Fiat. On the whole, the market had a very little variety to offer to consumers, whose numbers were also limited due to high prices and poor mileage of India-made cars. Technologically also, cars available in India were outdated, often produced with the discarded technologies of the developed world.

The idea of manufacturing small passenger cars for Indian consumers cropped up only in late sixties with Government of India approving Maruti Ltd's proposal for setting up a manufacturing plant in Gurgoan, in the vicinity of New Delhi. Though the company had no prior experience in automobile business, but it created huge interest and hope among media and the public at large because its owner (late) Sanjay Gandhi hailed from a powerful political family and therefore had a sound backing of the central government in power. However, contrary to expectations, Maruti's actual performance was poor and the company had to be liquidated in 1977. Another manufacturer Sipani entered into the scene in 1976. But its smaller production capacity could not make any mark in the Indian market. By 1980, India's annual production of cars was just above 30,000 and the market was shared among four domestic players, namely HM and PAL, SMPI and Sipani, though the market shares of first two far exceeded those of the last two. In the subsequent period, while HM and PAL managed to gain stronghold in Indian market, both SMPI and Sipani were closed down primarily due to their poor market performance.

\section{B. Second Phase: 1980-1990}

The second phase i.e. between 1980 and 1990 is a noteworthy period for the Indian passenger car industry. In fact, this can be considered as the "turning point" for the passenger car Industry as various developments of this period did play a key role in shaping its future.

In India, the Government considered car as a 'luxury' product to be used by rich, and the affluent. Therefore, development of car industry was accorded low priority in the governmental policy and planning. The automobile industry including its passenger car segment was highly regulated. Even the two-wheeler industry which serves lesser rich people was subjected to various government controls on firm's decisions regarding input usage and output levels. The licensed capacity of the industry was artificially kept lower than the actual market demand, resulting in long waiting period for two-wheelers, sometimes reaching up to two years or more. The passenger car segment, however, suffered from the problem of low demand. This along with heavy regulatory burdens on producers discouraged large scale manufacturing. The manufacturers preferred to remain satisfied with secured earnings from a limited yet protected market. As a result, the passenger car segment till end of seventies was not an industry that could catch the attention of the government, industry and the people.

However, things started changing as India entered into the decade of eighties. The country faced general election in early 1980 and the Congress Party came back to power at the centre. As part of rejuvenating the industrial growth in the country the new government took a number of initiatives including allowing a few joint ventures in commercial vehicle and two wheeler segments. The main idea behind this move was to supplement the country's public transport system that was already crippled due to overloading. Similarly, the need was also felt to encourage manufacturing of small cars at affordable cost that would allow middle income Indians an access to personal mobility. In this background, in 1981, the Government of India nationalized the defunct car factory at Gurgaon that gave rebirth to the Maruti Ltd. as Maruti Udyog Ltd. The seriousness of the government could be realized from the fact that soon after nationalization the search was on for a joint venture partner for supply of technology in small car manufacturing. After several negotiations, the deal was finalized with Japan's Suzuki Motor Company that acquired 26 percent stake in the new entity, called Maruti Suzuki.

The joint venture led to the beginning of a new era in India's automobile industry. Maruti started its production in 
December 1983 with an $800 \mathrm{cc}$ small car (Maruti 800). But within a short span of time it introduced new products like a Van (Omni) and a Jeep (Gypsy), apart from streamlining its existing model by adding a few new features like more leg space and higher fuel efficiency. Maruti cars gained instant popularity in India and very quickly they captured substantial market shares by fulfilling the unmet demand of yester years.

Entry of Maruti also helped in technological development of the industry. By bringing in cars at a low cost that were based on modern (and fuel-efficient) automobile technology, it galvanized the existing Indian firms to start upgrading their own technology, thereby initiating a modernization of the Indian passenger car industry [7]. In their bid to protect market shares from the new entrant Maruti, both HM and PAL took a number of steps like introducing new products with improved engines, higher fuel efficiency etc. While HM brought out Contessa Classic with Isuzu engine, the PAL introduced NE 118, a new model with Nissan engine and a new body from Fiat. The period also saw the beginning of modern auto component industry in India. Suzuki invested extensively in the Indian component manufacturers to improve the quality of the components and to reduce the cost of its component procurement [8].

\section{Third Phase: 1990-2000}

Unlike the previous decade, the present one started with a dull note. After two consecutive governments run by a single political party (Indian National Congress), the new government at the centre in 1989 was dependent on outside support from other political parties including the Bhartiya Janata Party (BJP), a national level party. The internal conflicts within the ruling party as well as political pressure from the partners like BJP reduced the effectiveness of the governance machinery and the country witnessed severe social unrests on caste and religious issues. As a result, politics got better of economics which, in turn, led to weakening of the economy. Finally, when the government fell and the election was held in 1991, the Indian economy was under severe balance of payment crunch.

In 1991, the Government of India in its attempt to overcome the crisis undertook economic liberalization programme that aimed at gradually removing various governmental controls from domestic production, foreign trade and other economic activities. The New Economic Policy kept a large number of industries out of government's licensing requirements. In June 1993, the Government of India came out with its new automobile policy that contained several measures like delicensing, automatic approval for foreign holding in Indian companies maximum up to 51 percent, abolition of phased manufacturing programme and reduction in excise and import duties. The policy also emphasized on indigenization of Indian automobile industry.

The favourable response from the industry to new policy could be gauged from the large scale entry of automobile companies into Indian market. All these new entrants were established players from leading automobile producing regions of the world, such as North America, Europe, Japan and Korea. Between 1991 and 1996, about a dozen of multi-national automobile firms entered into India and the list included all big names like Ford, GM, Honda, Hyundai,
Daewoo, Fiat, Mercedes-Benz, Peugeot etc. These foreign players formed joint ventures with Indian companies with the exception of Hyundai that instead established a wholly-owned subsidiary in India. Commenting on this development, Mukherjee wrote "the number of new entrants and the level of investment within a very narrow time window of two to three years is unprecedented and seems unique to India. Compared to three major models available in the Indian market until recently, customers can now choose from a wide variety of products" [9].

While customers felt happier due to wider choices, the manufacturers had to face stiff competition. In addition to new foreign firms, the Indian passenger car market had the presence of three established Indian companies, namely HM, PAL and Telco (renamed later as Tata Motors), and one Indo-Japanese joint venture, the Maruti Udyog Ltd. Though $\mathrm{HM}$ and PAL were struggling to maintain their market shares, the Telco with its long standing success in commercial vehicle segment posed as a new challenger to the existing firms. But in spite of plethora of players in the market, Maruti held its supremacy with more than 70 percent market share. The competitive market pressures forced the car makers to opt for advanced manufacturing technologies that meet environmental and safety standards. Moreover, automobile companies started building a country wide network to support after sales services. Another factor that helped the Indian market to grow during this period was auto financing which started emerging as an important driver for domestic demand.

\section{BEYOND 2000: THE DECADE OF INCESSANT GROWTH}

Starting in 2000, several landmark policy changes like removal of quantitative restrictions (QR) and 100 percent FDI through automatic route were introduced. Indigenously developed (Made in India) vehicles were introduced in the domestic market and exports were given a thrust. In the later years, keeping in view the long term development of the industry the Government of India came out with Automotive Mission Plan 2006-2016. Besides, policy initiatives the decade saw many new developments both within India and outside that shaped its future growth.

First, India like some of the other emerging market economies started showing its mark in the global automobile scene. At the beginning of the decade (2002), India's share in world car production was just 1.7 percent. But, by 2012, it rose to 5.2 percent, i.e. more than three-fold increase within a span of ten years. More importantly, in 2002 India's rank in world car production was $15^{\text {th }}$, which has since then improved gradually to $9^{\text {th }}$ in 2007 and again to $6^{\text {th }}$ in 2012 (Table II). This clearly establishes the rising power of India in global production of cars.

If India's rising power in global automobile scene is a point worth noticing, the dominant role of global players in domestic production and trade is no less fascinating. Though a large number of foreign OEMs from North America, Europe and East Asia did enter into India during the earlier decade (i.e. 1990s), their actual strength in the country could be felt only in recent years. Indian market still remains an 
attractive destination for foreign OEMs and the decade under review also witnessed entry of a few more automakers including the Volkswagen. At present, the global players collectively command about three-fourth of total production (2011) and more than 80 percent (2011-12) of all domestic sales of cars in India. Thus, India's ascent to global power was certainly helped by the presence of foreign players within India.

TABLE II: RISING SHARE OF INDIA IN WORLD CAR PRODUCTION

\begin{tabular}{|c|l|l|l|}
\hline Rank & \multicolumn{1}{|c|}{ Year 2002 } & \multicolumn{1}{|c|}{ Year 2007 } & Year 2012 \\
\hline 1 & Japan (20.84) & Japan (18.69) & China (24.61) \\
\hline 2 & Germany (12.39) & China (11.99) & Japan (13.56) \\
\hline 3 & USA (12.13) & Germany (10.73) & Germany (8.54) \\
\hline 4 & France (7.96) & USA (7.38) & S. Korea (6.61) \\
\hline 5 & S. Korea (6.41) & S. Korea (7.00) & USA (6.51) \\
\hline 6 & Spain (5.48) & France (4.79) & India (5.21) \\
\hline 7 & UK (3.94) & Brazil (4.49) & Brazil (4.16) \\
\hline 8 & Brazil (3.68) & Spain (4.13) & Russia (3.12) \\
\hline 9 & Canada (3.31) & India (3.22) & Mexico (2.87) \\
\hline 10 & Italy (2.72) & UK (2.88) & France (2.67) \\
\hline 11 & China (2.66) & Canada (2.52) & Spain (2.44) \\
\hline 15 & India (1.70) & Italy (1.71) & UK* (2.32) \\
\hline
\end{tabular}

Note: Figures in bracket indicate share (\%) in world production

*UK had $12^{\text {th }}$ rank in 2012

Source: Compiled from OICA data

Second, since 2002, the Indian car industry has experienced an incessant growth in all business indicators, such as production, domestic sales, export etc. This is something uncommon in the world automobile business of contemporary time, as most of the countries, big and small, had suffered huge losses in production, sales and hence profitability in the aftermath of economic slowdown of 2008. For instance, between 2007 and 2008 production of car fell approximately by $16 \%$ in France, $12 \%$ in Spain, $7 \%$ in South Korea, $6 \%$ in UK, $4 \%$ in USA and $3 \%$ in Germany. Japan, the leading producer of automobile in 2007, though lost only marginally during 2008, its production shrunk by more than $30 \%$ in the following year. In contrast, India not only could manage a positive growth rate during these difficult years, it had maintained a healthy growth throughout the decade. The SIAM data show that, in India, production of passenger vehicle has increased steadily from 2001-02 to 2011-12. Export of vehicles during the same period also shows a rising trend, except falling marginally by $0.41 \%$ in $2010-11$ (Fig.1). The only country that had done better than India in this decade is China, who acquired the number one position in car production in 2009 by dislodging Japan. China still continues with its first rank in 2012.

Third, like production and export, there has been a continuous rise in inflow of foreign direct investment (FDI) into India's automobile sector. From January 2000 to December 2011, cumulative FDI equity inflow in the automobile sector was US $\$ 6.6$ billion, which is about $4 \%$ per cent of total FDI inflows (US\$ 165.68 billion) into India during that period Out of this, US\$ 3.16 billion (i.e. about $48 \%$ ) was for the passenger car sub-sector. In terms of source countries, Japan alone accounted for more than one-fourth of all inflows. Year-wise data show that between 2005-06 and 2010-11, FDI equity inflow into automobile jumped by more than nine times from US\$ 143 million to US\$ 1331 million [10].

Finally, the last decade's biggest distinction lies in the attempt by Indian companies to go global. In the recent past we have noticed that some of the indigenous carmakers are now daring to go global not just for selling their made-in-India products but also for undertaking overseas manufacturing. Tata Motor's acquisition of Jaguar-Land Rover (JLR) from Ford in 2008 is definitely a move that points towards this trend. In short time, JLR has emerged as a good business for the Tatas and its encouraging performance has prompted the company to go for expansion within UK as well as outside locations like China. If Tatas succeed in opening its proposed plant in China, it will be one of the very few cases where an Indian (automobile) company undertaking manufacturing in China for catering to the needs of Chinese consumers. Besides Tata, another Indian automobile giant Mahindra \& Mahindra also has ambitious plans for global expansion. Suzuki's India operation is very critical for its overall business success as it contributes about one-fourth of global revenue and $40 \%$ of total volume. Suzuki is now planning to enter into African market through its Indian arm i.e. Maruti Suzuki India Ltd.

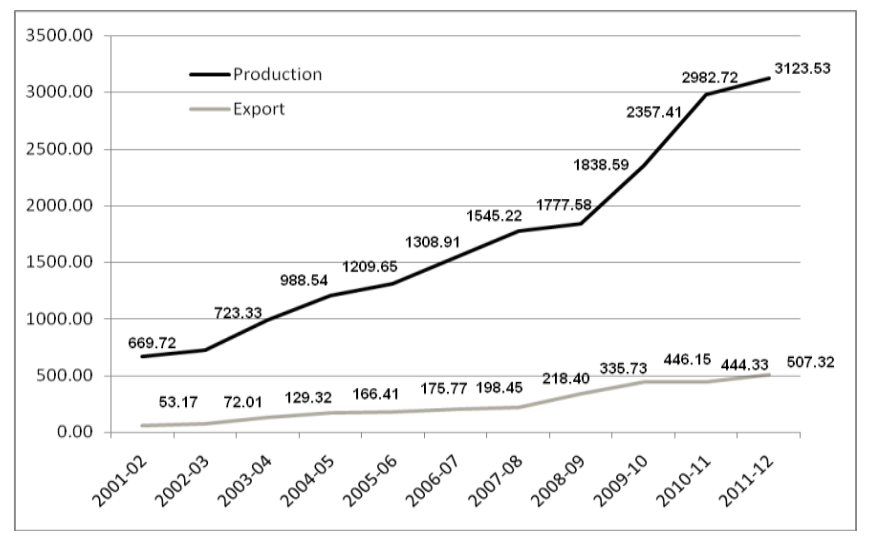

Note: Production and exports are in thousand numbers

Fig. 1. Growth in production and export of passenger vehicles in India

\section{REASONS FOR GOOD PERFORMANCE IN THE LAST DEACDE}

There are several factors that led to extraordinary performance of the Indian passenger car industry in the last decade. It would be perhaps difficult to capture all of them and even more difficult to isolate the contribution of each one in the overall growth process. However, in the following paragraphs an attempt has been made to identify the major ones.

First and the most obvious reason is the "India growth story". Research has established beyond doubt that automobile industry has crucial linkages with economic growth of nations. Demand for automobiles including cars generally increases in a growing economy. But, if growth halts for any reason, sales declines almost automatically and instantaneously. This was very much apparent from the recent developments in world economy post-2008. Fortunately, India had maintained a healthy growth rate 
throughout the last decade. During 2001-02 to 2010-11 Indian economy grew at an annual average rate of about 7.8 per cent which is quite impressive by global standard. Following the global economic crisis in 2008 , there was a decline in growth rate. But, India quickly regained the momentum by achieving 8.6 percent growth rate in 2009-10, which further increased to 9.3 per cent in 2010-11. During the last two years, however, the GDP growth rate has been sluggish, hovering around 5 to 6 per cent per annum [11]. But it is perceived that the current slowdown in India is more due to problems in the outside world coupled with 'policy paralysis' at home and the fundamentals of the economy are under no serious threat.

The composition of the growth is perhaps more relevant to our analysis. The last decade also saw a continuous rise in India's service economy, during which the growth rate in services sector far exceeded that of agriculture and industry combined. In this period, sectors like computer software (including IT-enable services), telecom, financial and commercial services etc. grew at a rapid pace and they emerged as important drivers for automobile demand in the country. A significantly large number of young professionals working in these sunrise sectors prefer using own cars to public transport. While this was partially necessitated by non availability of public transport facilities during late hours when most of them return from work, the freedom that a personalized mode of transport offers has been the main reason behind this trend. Factors such as affordability (supported by high income of these professionals) and better road conditions in cities have also contributed immensely towards this development.

Second, the decade was also accompanied by uprising of the Indian middle class. India, with a quarter of her total population falling in the so called 'middle class' category (approx. 300 million), is one of the largest consumer markets in the world. The collective purchasing power of the middle class is upwardly driving demand for all kinds of goods including automobiles. India's favourable demographics having a larger proportion of young men and women in total population combined with increasing per capita income has been a major attraction for global OEMs. Relatively low level of car penetration among Indian population is also a helpful factor in this regard. According to the World Bank data, in 2009 , India had only 18 motor vehicles per 1000 people. In comparison, it was 802 in USA, 593 in Japan, 564 in Germany, 355 in South Korea, 271 in Russia, 209 in Brazil (2008) and 47 in China [12].

Third, sometimes social factors play an important role in influencing the demand. In India, car is considered to be an 'aspirational good'. Therefore, ownership of car is not only meant for meeting personal transportation needs but also an important determinant of social status of the (car) owner. The model and make of the car, to a large extent, symbolizes how successful its owner is in his/her social life. A lot of car purchases in the country occur mainly due to this social reason.

The influence of social factors in demand gets amply demonstrated by the puzzle surrounding the low key performance of Tata Motor's Nano, the world's most affordable car. In spite of attractive price and high mileage, only 74, 521 units of Nano could be sold during 2011-12[13]. This is huge underperformance for a car meant for the mass market in a country having more than 1.2 billion population with low car penetration level. While this needs deeper probe, but on the periphery the image of the car as "poor man's vehicle" could be the single most important reason behind its apparent market failure. With steady GDP growth in the last decade, the aspiration level of average Indians has gone up over the years. Therefore, even an entry level buyer wants to possess a car that will improve his personal image as a "successful man". For this, he/she is ready to pay more or willing to wait a little longer if cannot afford now. Factors like this, though important, make Indian market a very complex place and at times confusing for many foreign OEMs who are still struggling to understand the market realities.

Fourth, the supply side developments are also important. On the supply side, the growth in Indian market was driven by certain happenings in the world of automobiles. After many years of dominance in their traditional territories such as North America, Europe and some other developed regions like Japan, the global automobile majors started looking towards new destinations. This move was mandated by two key developments. First, most of these markets were mature and also becoming victims of frequent business cycles. This offered very little scope for further growth. Secondly, production economics in such countries was not favourable to the manufacturers due to rising cost of raw materials and labour. Therefore, the automobile companies from North America, Europe and Japan were desperately looking for new markets for selling their products as well as new locations for undertaking low-cost manufacturing. However, this was not possible until the countries from the rest of the world were willing to open their economies for manufacturing and international trade. From 1990 onwards many economies including India adopted comprehensive economic reforms that allowed entry of foreign OEMs for trade and manufacturing. The entry of global players into the country in the previous decade as well in the current one, took the Indian passenger car industry to a new height with higher levels of production, sales and exports. Indian car market is now flooded with numerous makes and models. For instance, in the small car (hatchback) segment the current (2012) market offerings have as many as 30 models from about a dozen of manufacturers which include prominent carmakers of the world such as Toyota, Nissan, Honda, Hyundai GM, Ford, Skoda, Volkswagen, Renault etc., apart from Indian leaders like Maruti Suzuki, Tata Motors and Mahinda \& Mahindra. With new launches every now and then the number is bound to increase in future.

Fifth, the role of policy needs to be acknowledged. The kind of rapid growth that India's automobile sector had witnessed during the last decade or before that was not possible without favourable policy interventions. In this particular decade, the Government of India came out with two major policy pronouncements exclusively for the automobile sector, viz. Automobile Policy 2002 and Automotive Mission Plan 2006-2016. The 2002 (Auto) Policy had two major aims e.g. (a) making the Indian automotive industry globally competitive and (b) raising its 
contribution to Indian economy. The policy for the first time allowed $100 \%$ FDI in automobile sector via automatic route and discontinuation of foreign exchange neutrality requirement. These decisions definitely created a more conducive environment for the foreign investors. This comes clearly visible in the exponential growth in FDI into automotive sector over the period 2005-06 to 2010-11 (Fig. 2). Post-2002, leading car manufacturers like BMW and Volkswagen, who are known for their high quality standards, have set up their assembly shops in India by taking advantage of the new policy. Besides, following incentives for R\&D as pronounced by the policy, both Suzuki and Hyundai have established their R\&D facilities within India.

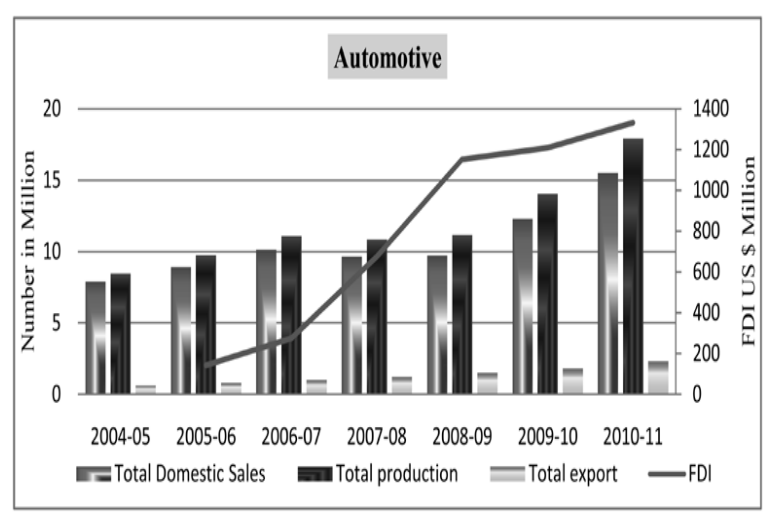

Fig. 2. Growth in FDI into automobiles vis-a-vis production and export Source: ASSOCHAM India [14]

Finally, the related and supporting industries have also played an important role in augmenting the growth of Indian passenger vehicle industry. Presence of a large and globally competitive auto component industry within the country was a positive factor that helped the automobile production to attain its much needed scale-economy. The period has also seen a good growth in technical education in India, wherein students' intake capacity in engineering and technical institutes throughout the country has gone up substantially. Though skill shortages is still a matter of serious concern in Indian industry, the rise in pass out numbers from these institutes over the years has certainly fuelled growth in automobiles sector by supplying technical manpower in adequate quantity, even if with less than required skill sets. On the demand side, availability of auto finance facilities from a large number of banks and financial institutions, sometimes also run in collaboration with the car manufacturers, has spurred demand for cars. Entry of leading car makers into the business of used cars (e.g. True Value by Maruti Suzuki) is another factor that might have favourably impacted upon this growth.

\section{SUMMARY AND CONCLUSIONS}

The automobile industry in India plays a very important role in the economy through its significant contribution in manufacturing output, export, employment generation and government revenue collection. The passenger vehicles segment though constitutes only 15 percent of all motor vehicles production in India, its real contribution is much more than what can be measured by its volume alone. The last decade (2002 to 2012) was quite a remarkable period for the Indian passenger car industry. During this time, the industry was in a continuous growth trajectory. The growth of the industry is visible in all key parameters such as production, sales, export etc. The inflow of foreign direct investments into the sector was also on the rise. This is a significant achievement for any industry to experience incessant growth over a long period such as a decade. This is even more noteworthy because a part of the period coincides with the post-2008 economic crises during which the world automobile industry was in turmoil. Between 2007 and 2008, production of car fell in all leading automobile producing nations such as France (16\%), Spain (12\%), South Korea (7\%), UK (6\%), USA (4\%) and Germany (3\%). Japan's loss in production was above $30 \%$ in the next year. In contrast, India not only could manage a positive growth rate during these difficult years, it had maintained a healthy growth throughout the decade. By 2012, India emerged as the sixth largest producers of cars in the world. The country also hosts as many as 19 manufacturers of passenger cars and multi-utility vehicles including the major global OEMs.

The stupendous success of the Indian passenger vehicle industry in the last decade has created huge interests among the analysts, policy makers and researchers. The question that is being asked frequently is how India could do so well in the midst of global uncertainties. China is perhaps the only country that has done better than India during this period. In this paper an attempt has been made to answer this key question. While finding a comprehensive answer is not an easy task and may be beyond the scope of a single research like this, the paper tries to unfold the mystery behind India's unprecedented success in the last decade.

The most important factor to be identified is India's economic growth rate. It is an established fact that growth in economy and automobile industry generally gel well. The automobile industry had the advantage of India's healthy growth rate that averaged 7.8 per cent during 2001-02 to 2010-11. More particularly, a major chunk of this growth had its origin in the services sector, which acted as an important growth driver for car demand in the country. A growing economy with relatively low growth in population helped in a steadily rising per capita income. This led to uprising of India's 350 million strong middle class populations, who were in demand for lot of goods including cars.

India's crippling public transport infrastructure, mainly caused by overloading, and improvement in road networks, particularly in big cities have also contributed towards this growth. But social factor like the pride in car ownership was no less important in the context of India. On the supply side, slow growth in matured markets like USA, EU and Japan accompanied by rising cost of production due to increasing material and labour cost forced many global majors to look for new markets a well as low-cost manufacturing locations. During the same period, economic reforms measures were initiated in emerging market economies and some other parts of the world. This facilitated entry of global OEMs into those regions where demand is high, but cost of production is relatively low. The Indian passenger vehicle industry has remained a beneficiary of this global shift process. During the decade under discussion and even before that many global OEMs had entered into Indian market and their combined 
efforts have substantially augmented production and sales of vehicles within and outside India. The dominance of global players in India comes apparent from the facts that now they collectively command about three-fourths of total production and more than 80 percent of all domestic sales. So India's ascent to global power was largely possible by the proactive role of global players in the domestic arena.

The other factors that had contributed in India's growth story include favourable governmental policies and the positive role played by related and supporting industries. Since early eighties, the automobile industry has always been the focus of government's economic policy and planning. Several policy initiatives have been taken by the Government of India from time to time to strengthen the automobile industry because of its criticality in production, employment and exports. In the last decade also the government came out with an auto policy in 2002 and a ten-year mission plan starting 2006. These policies and other policies of the past have undoubtedly helped the industry to grow and come to the stage it is now. Presence of a globally competitive auto component industry, availability of technical manpower at relatively low cost, auto finance facilities, emergence of used car market in India etc. are some other factors that caused growth in India's passenger car industry.

But the automobile sector also confronts numerous future challenges. The industry forecast says that growth in demand may remain subdued in the next one or two years. Otherwise also, as the market matures and car penetration level increases, the demand may rise rather slowly. The industry also suffers from existence of excess capacity not allowing many firms to reap full benefits of economies of scale. This coupled with sluggish demand may not encourage many OEMs to go for capacity expansion and future investment in R\&D may dry up. Rising fuel prices in India along with a significant difference between petrol and diesel prices is another nagging problem faced by the vehicle manufacturers. The consumer preference is very much clear in favour of diesel run vehicles. This is visible from the fact that while, in 2005 , diesel vehicles constituted only $20 \%$ of all vehicles on road; by 2012 it went up to $43 \%$ [15]. But there is a lack of clarity in government policies on fuel pricing, especially in an uncertain political atmosphere that may last at least till general election in 2014. The stiff competition in domestic market in the face of slow growth prospects may compel many manufacturers to opt for cost reduction. Here again, it would be very tough for the OEMs to do anything significant as most of material prices are on the rise and wage cut remains a difficult choice after incidents of labour unrests reported from many places, notably the Maruti Suzuki's Manesar plant. However, it is the time to rejoice the achievement even though the future may not look as bright as the past.

\section{REFERENCES}

[1] NDTV, Tata Motor's sales down in March. (1 $1^{\text {st }}$ April 2013). [Online]. Available: http://profit.ndtv.com/news

[2] OICA, [Online]. http://oica.net/category/economic-contributions.

Available:

[3] Government of India, Economic Survey 2011-12. [Online]. Available: http://pib.nic.in/archieve/esurvey/esurvey2011/eng2011.pdf

[4] Government of India, National Electric Mobility Mission Plan 2020, August 2012.

[5] Auto Component Manufacturers Association of India (ACMA), Auto Component Industry in India: Growing Capabilities \& Strengths, 2011.

[6] SIAM, Industry Statistics. [Online]. Available: http://www.siamindia.com.

[7] D. S. Ambuj and C. Pankaj, "Technological Change in the Indian Passenger Car Industry,” BCSIA Discussion Paper 2004-05, Energy Technology Innovation Project, Kennedy School of Government, Harvard University, 2004.

[8] K. J. R. N. Amar, "FDI Model in Emerging Economies: Case of Suzuki Motor Corporation in India," The Journal of American Academy of Business, Cambridge, March 2005.

[9] A. Mukherjee, "The Indian Automotive Industry: Speeding into the Future?" Actes du Gerpisa, vol. 28, pp. 35-53, February 2000.

[10] Government of India, Department of Industrial Policy and Promotion. [Online]. www.dipp.nic.in/Publications/FDI_Statistics/2011/india

[11] Economic Advisory Council to the Prime Minister, Review of the Economy. (April 2013). [Online]. Available: http://eac.gov.in/Review of the Economy 2012-13_EAC to PM.pdf

[12] World Bank. [Online]. Available: http://data.worldbank.org/indicator/IS.VEH.NVEH.P3/countries?displ ay=default/

[13] Tata Motors $67^{\text {th }}$ Annual Report 2011-12. [Online]. Available: http://tatamotors.com/investors/financials/67-ar-html/home.html

[14] ASSOCHAM India, "India's Experience with FDI: Role of a Game Changer," The Associated Chambers of Commerce and Industry of India, January 2012

[15] CARE Research, Industry Update-Indian Passenger Vehicle Industry, December 2012.

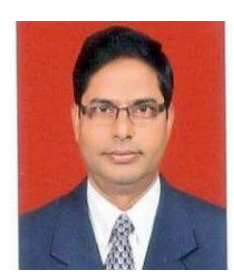

Utpal Chattopadhyay is currently working as assistant professor (Economics Area) at National Institute of Industrial Engineering (NITIE), Vihar Lake, Mumbai, India.

Prior to joining NITIE, Mumbai in 2008, he had worked with the National Productivity Council of India's headquarters in New Delhi as Deputy Director /Assistant Director. He also had an opportunity to work in a research project at the Indian School of Mines, Dhanbad, India.

Dr. Chattopadhyay holds Phd degree in Economics from Delhi University and M.Sc(Economics) from Calcutta University. He has been trained by the Asian Productivity Organization (APO), Tokyo on several topics such as productivity measurement, inter-firm comparison, knowledge management etc Dr. Chattopadhyay's teaching and research interests include areas like managerial economics, global competitiveness, economic environment of business and international trade issues. He has to his credit more than twenty research papers either published in journals and/or presented in various international conferences held in India and abroad. 